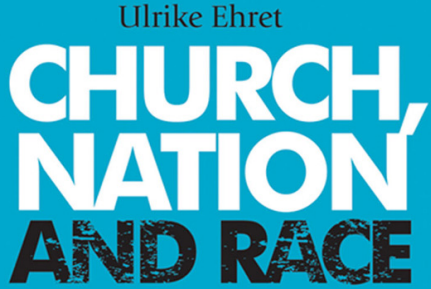

Catholics and antisemitism in Germany and England, 1918-45

\title{
Die Pavteicu!
}

\section{Spartalus. \\ Soyil \\ Unabhängige \\ Sosit}
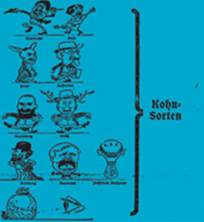

Deatidit seraohrefilde partet

$\overline{\substack{\text { Clowifticbe } \\ \text { Dolfopartei }}}$
volfspartei

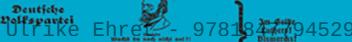

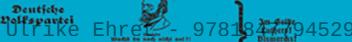
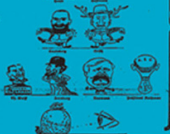

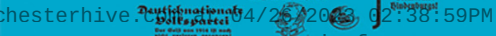

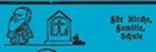

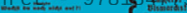
Con

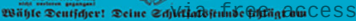


Church, nation and race

\section{MANCHESTER 1824}

Manchester University Press 
Ulrike Ehret - 9781847794529

Downloaded from manchesterhive.com at $04 / 26 / 2023$ 02:38:59PM via free access 


\title{
Church, nation and race
}

\section{Catholics and antisemitism in Germany and England, 1918-1945}

\author{
Ulrike Ehret
}

\author{
Manchester University Press \\ Manchester and New York
}


Copyright (C) Ulrike Ehret 2012

The right of Ulrike Ehret to be identified as the author of this work has been asserted by her in accordance with the Copyright, Designs and Patents Act 1988.

Published by Manchester University Press

Oxford Road, Manchester M13 9NR, UK

and Room 400, 175 Fifth Avenue, New York, NY 10010, USA

www.manchesteruniversitypress.co.uk

Distributed in the United States exclusively by

Palgrave Macmillan, 175 Fifth Avenue, New York,

NY 10010, USA

Distributed in Canada exclusively by

UBC Press, University of British Columbia, 2029 West Mall,

Vancouver, BC, Canada V6T 1Z2

British Library Cataloguing-in-Publication Data

A catalogue record for this book is available from the British Library

Library of Congress Cataloging-in-Publication Data applied for

ISBN 9780719079436 hardback

First published 2012

The publisher has no responsibility for the persistence or accuracy of URLs for any external or third-party internet websites referred to in this book, and does not guarantee that any content on such websites is, or will remain, accurate or appropriate.

Typeset

by 4word Ltd, Bristol

Printed in Great Britain

by TJ International Ltd, Padstow 